\title{
THE VALIDITY OF THE CALCULATION OF STANDARD UREA CLEARANCES FROM LOW URINE VOLUMES
}

\author{
By LEON C. CHESLEY \\ (From the Department of Biochemistry, Margaret Hague Maternity Hospital, \\ Jersey City)
}

(Received for publication March 18, 1937)

The "standard urea clearance" is calculated upon the assumption that the urea excretion will vary with the square root of the urine volume, when the latter is below the augmentation limit of about two milliliters per minute. The result of the calculation gives the milliliters of blood which would be cleared were the urine volume one milliliter per minute, if the square root rule were strictly true.

Möller, McIntosh and Van Slyke (1) derived the equation for computing the standard urea clearance as follows: "If $C$ is the observed blood urea clearance (the cubic centimeters of blood, the urea of which is excreted in one minute) with any urine volume output, $V$, below the augmentation limit, then with the standard urine volume, $V_{8}$, the corresponding standard clearance, $C_{8}$, may be calculated by the square root rule as:

$$
\text { C) } \begin{aligned}
C_{a}: C & =\sqrt{V_{a}}: \sqrt{V}, \text { or } \\
C_{a} & =C \sqrt{\frac{V_{a}}{V}} .
\end{aligned}
$$

Taking the standard urine volume as $1 \mathrm{ml}$. per minute,

$$
C_{s}=C \sqrt{\frac{1}{V}}
$$

Substituting the determinable factors for $C$,

$$
C_{s}=\frac{U V}{B} \sqrt{\frac{1}{V}}, \text { whence }
$$

Standard clearance $=C_{s}=\frac{U \sqrt{V}}{B}$.

If the square root rule should not be valid over any range of urine volumes, then the standard clearance could not be calculated from urines in that range.

Austin, Stillman and Van Slyke (2), and Möller, McIntosh, and Van Slyke $(1,3)$ have shown that the square root rule does obtain over the range of ordinary urine volumes up to the augmentation limit, in both normal and nephritic individuals.

However, in the range of minimal urine volumes, i.e. below $0.4 \mathrm{ml}$. per minute, the papers of these authors contain few data. The lowest urine volume at which they measured the urea excretion was $0.21 \mathrm{ml}$. per minute. Other observations were made with minute volumes of 0.25 , $0.28,0.29,0.30$, and $0.32 \mathrm{ml}$. In all of these, the urea excretion fell below the theoretical (shown in Figure 1 as $y$ ).

Is the calculation of the standard clearance valid when the urine output is very low? The data to be presented here seem to show that it is not.

In pregnancy toxemias, acute nephritis, cardiac decompensation, fever, and other conditions, there may be marked oliguria, and the minute volume of urine will fall below the range investigated by Van Slyke and his collaborators.

Clearances calculated at such times may be grossly in error. Incompleteness of urine collection at this time will introduce a large percentage error which may be avoided by doing twenty-four hour clearances. The error due to the failure of the square root law can not be thus obviated.

\section{METHODS}

The urea clearance was determined exactly as outlined by Möller, McIntosh, and Van Slyke (1) with the exception that in many of these special cases more water was given, as will be explained below.

Van Slyke's (4) gasometric methods were used for both blood and urine urea.

The data reported were obtained from 169 cases of pregnancy toxemia and Bright's disease complicated by pregnancy. Four normal nonpregnant adults were also studied. The relevant data from published papers of some other investigators are also considered. 


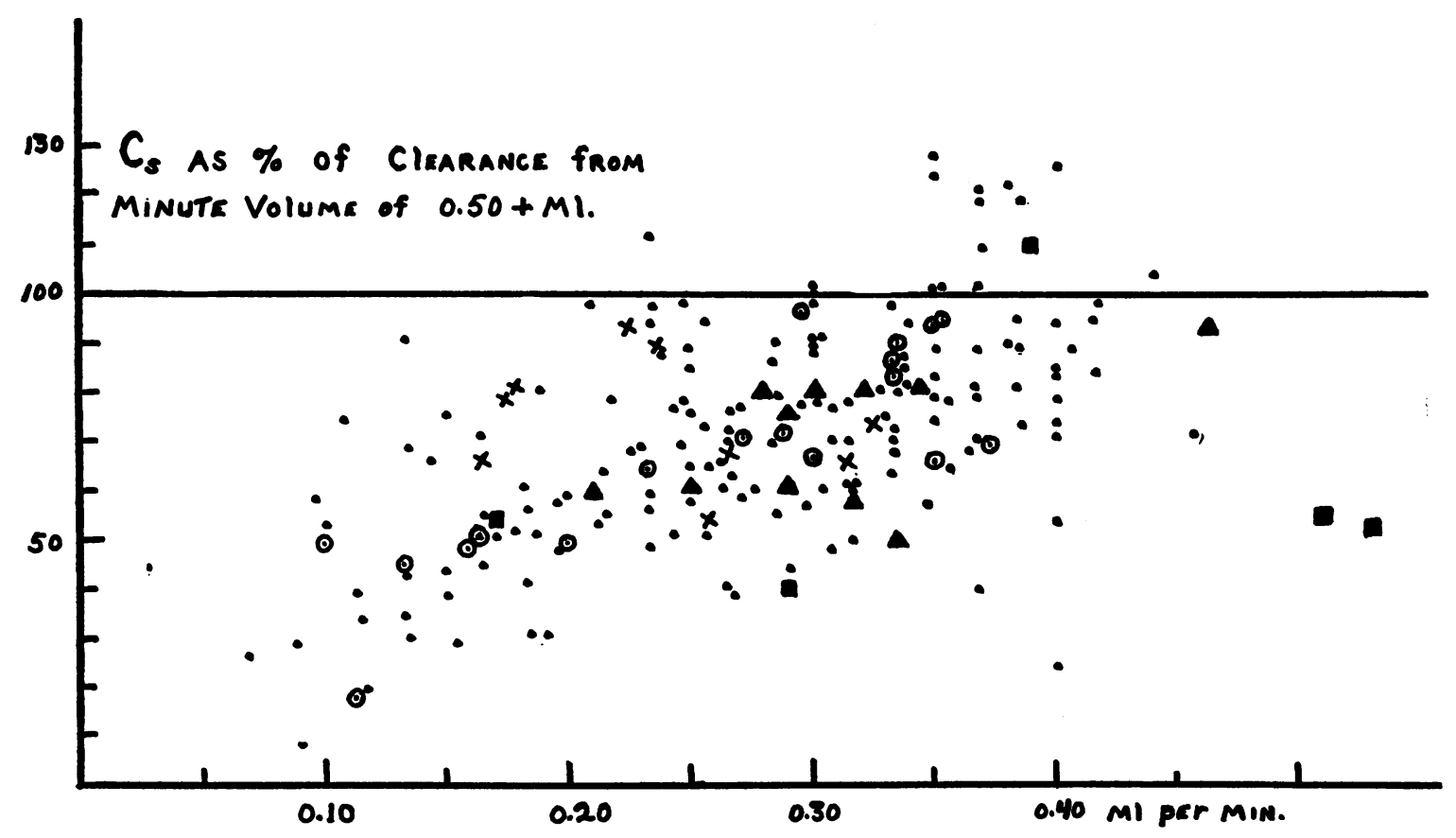

Fig. 1. The Influence of Urine Volume upon the Calculated Urea Clearance

The standard clearance calculated from the lower or lowest urine volume is plotted as per cent of the clearance calculated from a volume of $0.50 \mathrm{ml}$. or more.

- Pregnancy toxemia.

$\odot$ Bright's disease complicated by pregnancy.

$\times$ Normal.

$\triangle$ Data of Möller, McIntosh, and Van Slyke $(1,3)$ and Austin, Stillman, and Van Slyke (2) for normal and nephritic individuals.

- Data of Cullen, Nelson, and Holmes (5) for nephritic children.

\section{RESULTS}

The observations in 169 cases of pregnancy toxemia are summarized in Figure 1. This figure also shows all of the relevant data published in the papers alluded to above, together with a recalculation of Cullen, Nelson, and Holmes' (5) observations on nephritic children. In the graph, the patient's lower or lowest clearance has been plotted as per cent of the higher or highest clearance determined in the preceding or succeeding $\operatorname{hour}(\mathrm{s})$. This was done so as to include data from chronic nephritics.

It is obvious from the graph that the lower the minute urine volume, below about $0.35 \mathrm{ml}$., the greater the downward deviation of the calculated standard clearance below the level computed from the higher urine volume. This limiting volume, of about $0.35 \mathrm{ml}$., we shall call the critical volume. Below it the square root law does not appear to be valid, and the farther the volume sinks below it the greater becomes the error in calculating the standard clearance.

The distribution of the different symbols on the graph indicates that the toxemia patients are not peculiar in regard to this deviation from the square root rule of urea excretion. Chronic nephritic patients show the same dependence upon urine volume for the maintenance of a urea clearance level predicted from the rule. The four normal adults studied show the same dependence. Furthermore, these data find support in the published work of Van Slyke and his collaborators. Most of Cullen's observations fall below the mean range of the other points; perhaps this is because the corrected urine volume rather than the actual volume was plotted.

Since we are dealing with small urine volumes, the failure completely to drain the bladder at any 
collection during the test would result in large errors. Such errors have undoubtedly crept into some of the cases reported here. However, this error cannot explain the consistent findings shown in Figure 1. The points, with few exceptions, are fairly uniform in distribution and with decreasing urine volume progressively fall lower and lower on the graph. Every clearance observed with low urine volumes, during 1935 and 1936, is shown in Figure 1, which therefore represents wholly unselected cases.

In 12 patients and 3 normals, three or more successive hourly clearances were done. These are instructive. In some cases, two closely checking clearances were obtained with urine volumes above the critical limit, while the clearance obtained with the small urine volume was much lower. In these cases, one can hardly attribute the low clearance to incomplete collection of the urine. In other cases, with two different volumes below $0.35 \mathrm{ml}$., and one above, the clearance rises with the increase in volume. In still other instances, low clearances check as calculated from similar low volumes, while a high clearance is observed above the critical volume.

Usually the higher urine volume and higher clearance were observed in the second of two or the last of three hourly clearances. This is because the patient was given extra water if the first urine volume was low. A still greater factor is that she was beginning belatedly to excrete the previously ingested water. This slow excretion of water is a well known characteristic in pregnancy toxemia. But in 36 cases, the first urine specimen had the higher volume and showed the higher clearance.

Apparently the critical urine volume is about $0.35 \mathrm{ml}$. per minute, or possibly a little higher (21 $\mathrm{ml}$. per hour or more). This checks fairly well with Maddock and Coller's (6) recalculation of Lashmet and Newburgh's observations. They show that with an upper specific gravity of 1.024 , there must be voided at least $605 \mathrm{ml}$. of urine in twenty-four hours if $\mathbf{3 5}$ grams of waste are to be excreted. When a specific gravity of 1.032 is attained, at least $473 \mathrm{ml}$. are needed. (These volumes would be 0.42 and $0.329 \mathrm{ml}$. per minute.)

The critical urine volume, below which the square root rule fails, apparently varies with the individual. Van Slyke has found a similar varia-
TABLE I

The effect of low urine volume upon the calculated standard urea clearance. Determinations made in successive hours. Normal adults and patients with pregnancy toxemia. Also shown in Figure 1.

\begin{tabular}{|c|c|c|c|c|c|c|c|}
\hline $\begin{array}{c}\text { Vol- } \\
\text { ume } \\
\text { output }\end{array}$ & $\begin{array}{l}\text { Calcu- } \\
\text { lated } \\
C_{8}\end{array}$ & $U / B$ & $\begin{array}{c}\text { Blood } \\
\text { urea } \\
\text { ittrogen }\end{array}$ & $\begin{array}{c}\text { Vol- } \\
\text { ume } \\
\text { output }\end{array}$ & $\begin{array}{l}\text { Calcu- } \\
\text { lated } \\
C_{8}\end{array}$ & $|\boldsymbol{U}|$ & $\begin{array}{c}\text { Blood } \\
\text { urea ni- } \\
\text { trogen }\end{array}$ \\
\hline$\underset{\text { per }}{\text { per. }}$ & per cent & & pgm. & ml. & per cent & & mgm. \\
\hline 0.262 & 68 & 72 & & 0.333 & 125 & 117 & \\
\hline $\begin{array}{l}0.323 \\
0.258\end{array}$ & $\begin{array}{l}74 \\
54\end{array}$ & $\begin{array}{l}71 \\
57\end{array}$ & & $\begin{array}{l}0.164 \\
0.733\end{array}$ & $\begin{array}{r}68 \\
151\end{array}$ & $\begin{array}{l}92 \\
97\end{array}$ & 7.5 \\
\hline $\begin{array}{l}0.313 \\
0.517\end{array}$ & $\begin{array}{r}66 \\
101\end{array}$ & $\begin{array}{l}63 \\
74\end{array}$ & $\begin{array}{c}\text { (Normal) } \\
22.0\end{array}$ & .750 & 142 & 89 & \\
\hline 0.173 & 79 & 103 & & $\begin{array}{l}0.216 \\
0.458\end{array}$ & $\begin{array}{r}77 \\
102\end{array}$ & $\begin{array}{l}90 \\
82\end{array}$ & 8.6 \\
\hline 0.234 & 89 & 99 & (Normal) & & & & \\
\hline 0.225 & $\begin{array}{l}100 \\
94\end{array}$ & $\begin{array}{l}108 \\
107\end{array}$ & 12.4 & & $\begin{array}{r}62 \\
89\end{array}$ & $\begin{array}{l}79 \\
93 \\
01\end{array}$ & 142 \\
\hline 0.167 & 67 & 88 & & & & & $1 \times .0$ \\
\hline 1.100 & 110 & 57 & (Normal) & 0.167 & 58 & 77 & \\
\hline 13.950 & 109 & & & $\begin{array}{l}0.517 \\
0.968\end{array}$ & $\begin{array}{l}89 \\
84\end{array}$ & $\begin{array}{l}67 \\
46\end{array}$ & 9.5 \\
\hline 0.173 & 82 & 106 & (Normal) & & & & \\
\hline & 128 & 103 & & $\mid \begin{array}{l}0.083 \\
0.191\end{array}$ & $\begin{array}{l}14 \\
48\end{array}$ & $\begin{array}{l}28 \\
59\end{array}$ & \\
\hline $\begin{array}{l}0.150 \\
0.450\end{array}$ & $\begin{array}{r}45 \\
102\end{array}$ & $\begin{array}{l}63 \\
82\end{array}$ & & 1.000 & 158 & 86 & 13.0 \\
\hline & 92 & 69 & 13.2 & $\mid \begin{array}{l}0.233 \\
0.567\end{array}$ & $\begin{array}{l}49 \\
76\end{array}$ & $\begin{array}{l}56 \\
54\end{array}$ & 7.9 \\
\hline $\begin{array}{l}0.115 \\
6.700 \\
9.250\end{array}$ & $\begin{array}{l}24 \\
71 \\
67\end{array}$ & 79 & 9.8 & $\begin{array}{l}0.113 \\
0.700\end{array}$ & $\begin{array}{l}28 \\
72\end{array}$ & $\begin{array}{l}42 \\
46\end{array}$ & 8.2 \\
\hline $\begin{array}{l}0.182 \\
0.241 \\
1.350\end{array}$ & $\begin{array}{l}34 \\
42 \\
81\end{array}$ & $\begin{array}{l}43 \\
46\end{array}$ & 11.6 & $\begin{array}{l}0.162 \\
0.429\end{array}$ & $\begin{array}{l}14 \\
28\end{array}$ & $\begin{array}{l}18 \\
24\end{array}$ & 26.7 \\
\hline
\end{tabular}

tion in the augmentation limit. This difference may be seen in the normals A and B, Table I. By virtue of a higher urea concentration ratio, $B$ was able to maintain a urea clearance of 100 per cent with a minute urine volume of $0.25 \mathrm{ml}$. A, with the same urine volume, showed a clearance of 54 per cent.

The reason for the failure of the square root law at these low urine volumes is not merely that the urea concentration fails to increase with the decreasing volume, as postulated. As the urine volume continues to fall, the urea concentration ratio reverses its trend and now decreases. This is shown in many of the cases in Table I.

\section{DISCUSSION}

Calculation of the standard clearance from very small urine volumes apparently will give results considerably too low. This has been a stumbling block in several papers, particularly in those discussing renal function in pregnancy toxemia. 
For instance, Dieckmann (7) has reported urea clearances of less than 39 per cent in $2 / 3$ of ante partum toxemic multiparæ with no history of previous toxemia or renal disease.

This does not seem reasonable. When one sees that the blood urea nitrogen for this group was $15.4 \pm 0.74$, he can not accept these low clearances. The difficulty is resolved when one studies Dieckmann's Table II, Section B. The mean minute volume for the group mentioned was 0.643 ml., with a standard deviation of $0.408 \mathrm{ml}$.

Several writers have reported low urea clearances in eclampsia. Others believe that low clearances are found at the height of pregnancy toxemia. Since oliguria is very often found at the height of toxemia, one may probably attribute these findings to the oliguria and not to renal damage. The urea clearance was found by Chesley (8) to be normal in preëclampsia, eclampsia, and hypertension. The clearances did not differ significantly from values found for normal pregnant and puerperal women. No clearance was included unless calculated from a urine volume in excess of $0.35 \mathrm{ml}$. per minute.

Many of the low standard clearances calculated in acute nephritis are probably too low, because of the oliguria. This may be true in cases showing a normal specific gravity but a low clearance. According to Fishberg (9) the scanty urine of a patient with acute nephritis may show a high or a low specific gravity. If the specific gravity be high, the oliguria is of extrarenal origin, and the kidney damage is not extensive. When the specific gravity is low with oliguria, then the renal function has been measurably impaired. Alving and Van Slyke (10) found the specific gravity test to be a more sensitive measure of kidney impairment than is the urea clearance. This, they say, is also true in acute nephritis.

\section{SUMMARY AND CONCLUSIONS}

The square root formula for calculating the standard urea clearance gives erroneously low results when the urine flow falls below a critical volume, which for adults is about $0.35 \mathrm{ml}$. per minute. When the urine collected in an hour's clearance test falls below $20 \mathrm{cc}$, the test should be discarded.

Below this critical urine volume, the U/B reverses its trend and decreases with further volume decrease.

The influence of small urine volume upon the calculated standard clearance is discussed with regard to findings in pregnancy toxemia and acute nephritis.

I wish to thank Dr. D. D. Van Slyke for his graciousness in discussing these data with me. I am also indebted to Dr. S. A. Cosgrove and Dr. N. M. Alter for reading the typescript and for the opportunity to use the toxemia patients available at the Margaret Hague Maternity Hospital.

\section{BIBLIOGRAPHY}

1. Möller, E., McIntosh, J. F., and Van Slyke, D. D., Studies of urea excretion. II. Relationship between urine volume and the rate of urea excretion by normal adults. J. Clin. Invest., 1929, 6, 427.

2. Austin, J. H., Stillman, E., and Van Slyke, D. D., Factors governing the excretion rate of urea. J. Biol. Chem., 1921, 46, 91.

3. Möller, E., McIntosh, J. F., and Van Slyke, D. D., Studies of urea excretion. IV. Relationship between urine volume and rate of urea excretion by patients with Bright's disease. J. Clin. Invest., 1929, 6, 485.

4. Van Slyke, D. D., Determination of urea by gasometric measurement of the carbon dioxide formed by the action of urease. J. Biol. Chem., 1927, 73, 695.

5. Cullen, G. E., Nelson, W. E., and Holmes, F. E., Studies of kidney function in children. I. Urea clearance values: (1) no evidence of kidney disease, (2) after acute hematuric nephritis following an acute infection, (3) in the acute stage of hematuric nephritis. J. Clin. Invest., 1935, 14, 563.

6. Maddock, W. G., and Coller, F. A., Water balance in surgery. J. A. M. A., 1937, 108, 1.

7. Dieckmann, W. J., Renal function in the toxemias of pregnancy. Am. J. Obst. and Gynec., 1935, 29, 472.

8. Chesley, L. C., Renal function tests in the differentiation of Bright's disease from specific toxemias of pregnancy. (In preparation.)

9. Fishberg, A. M., Hypertension and Nephritis. Lea and Febiger, Philadelphia, 1934, 3d ed.

10. Alving, A. S., and Van Slyke, D. D., The significance of concentration and dilution tests in Bright's disease. J. Clin. Invest., 1934, 13, 969. 